\title{
Impact of Corporate Governance on Cash to Cashflow Sensitivity Evidence from Pakistani Manufacturing Firms
}

\author{
Khalid Razzaq, Mr. Naeem-Ullah \\ MBA (cont.) Fall 2012 \\ (Assistant Professor)
}

\begin{abstract}
The study was conducted with the objective to investigate whether Pakistani manufacturing firms listed on KSE-100 index hold more cash out of their cashholding by augmenting Almedia et al. (2004) regression equation with corporate governance indicators. The study concluded with having positive significant coefficient for cashflow, mbr and variability while the corporate governance indicators of $C E O$ duality indicates that in the presence of CEO duality cashholding tend to be low. However no evidence was found corporate governance indicators and number of executive directors and non-executive directors fell to impact any cashholding pattern of the firms.
\end{abstract}

Key words: Cash Holding, KSE-100 index, Manufacturing Firms.

\section{Introduction:}

In the recent times the role of effective corporate governance has been realized and now it is crucial in all economic and financial transactions and in developed and developing economies. Corporative governance in corporation can act a vital part in mitigating informal firms imperfections along that the smooth running of business operations (Dittmar and Mahrt, 2007).Corporate Governance is not fixes in business tasks performing but it is quite different in nature and may be that is the reason why different people have different view of corporate governance as from the point view of the stakeholders mainly employees and shareholders different tasks are performed.

Attig, et al said in their research in 2012 that the staffs opinion in that the responsibility of commercial instructor is to guarantee flat successively of the corporate provide plunders and advantages to the workers on the presentation from the beginning and having the opinions of investors to confirm their jobs is optimistic profits on their financing of them. In the defined condition, however argument build that commercial authority can be defined in relationships of a structure which helps commercial coordination and trend. In Pakistan alternative situation of commercial authority, which rises due to unproductive observation and adaptable plan, is that the leaders and managers are financing cash in dangerous plans deprived of discussion other investors.(Kusnadi in year 2005). Other opinion in this situation is that big families businesses, in which panel of management have the most volume of stocks, underneath such situations panel of management have improved control on bondholders cash flows and judgments. The connection among the commercial authority and mangers in case of Pakistan is so me times opportunity to be adverse but the factual form of the connection cannot be defined as the connection is non-monotonic (Kusnadi, 2005). Kusnadi in the year 2005 said that, the connection among the commercial authority and managers in case of Pakistan is sometimes opportunity to be adverse. But the factualform of the connection cannot be defined as the connection is non-monastic.

The investing in risky projects decisions can be lead to financial crisis or bankruptcy in the firms and the main causes of financial crisis were reported to be borrowing excessive, standards of low mortgage etc. (Wei and Zhang, 2008). In this paper will be highlight on the relationship between the cash, variability, size and market value of firms all of these are the corporate governance determinants. It's a common observation there are no well-defined laws and regulations in countries for the shareholders or the shareholders rights are not protected well enough in those countries corporation has to hold more cash as compared to the corporations in the developed countries (Dittmar, Mahrt-Smith and Serves, 2003).

\section{Literature Review:}

Keynesian theory of investment which is also regarded as preference liquidity approach explains the cash of demand and liquid assets of the organization. In this theory can also be described in perspective of identifying organization investment. Management of cash in any those of organization is conducted by three main motives. These are: 1) business deal motive, 2) cautionary motive, and 3) speculative motive. Keynesian investment Theory regarded that precautionary motive is highly linked with the savings and intentions investment of individuals. This is because that how people to develop desire to save money for using in uncertain future (Keynes, 1936). When they have large amount of money, they can put those money into investment. In point view of organizations, Keynesian theory suggests that having large amount of cash enables 
an organization to avoid transactions for accessing external finance and also for investing in opportunities prospective. Regarding cash sensitivity, Keynes' precautionary motive is to be highly considered. This motive also develops desire in investors to save money for uncertain events. According to this theory, the main idea is to search for reliable sources of obtaining cash and investing in opportunities perspective. The idea of cash sensitivity can be related with the Keynes Theory which emphasizes the potential of cost related with conversion of fixed assets into liquid assets such as cash. Keynes (1936) has evaluated that organizations need to consider the transaction cost related with converting fixed assets into cash. The second motivate in this regard described by Keynes (1936) was precautionary motive. Modigliani and Miller (1958) also argued that financial policy of a firm is irrelevant to the real decisions taken by management.

Fazzari et al. (1988) evaluated that manufacturing firm's face financial constraints depict large cash flow sensitivity. According to this external and internal factors can also play crucial role. They found evidence that firms which dividend payout low as smaller size and high growth rates have high cash flow sensitivity. They suggested that cash flow sensitivity and marginal value of cash are negatively related with each other. This is because when firms have low cash, it is more likely that marginal cost of increases cash of sending. Therefore, marginal value of cash is the most important factor in determining the investment choices in firms. Harford, Mansi and Maxwell (2005) have suggested that asymmetric information is the key factor which impacts cash in organization. The probability of cash increases with high level of asymmetry in information. On the other hand, Zingales and Kaplan (1997) indicate inverse relationship between these variables. He was of the view that variability is also an essential factor which impacts on cash flow sensitivity in firms.

On the other hand, Almeida et al. (2004) suggested that precautionary motive of cash is mainly applicable for firms which have financial constraints but not their counterparts who do not have financial constraints. Cash can also be impacted through tax incentives. The tax motive has explored that liquidity aspects are also impacted through tax incentives available to the organizations (Foley, Hartzell, Titman and Twite, 2007). They devised a model for identifying the association between liquidity behavior and financial constraints of organization. They stated that firms hold cash when they anticipate that firms will face financial difficulties in future. In the same view, authors have suggested that cash held by organizations is optimized for creating balance in the profitability of future and current investments in organizations. Organizations that is not restricted to compelled want to hold cash reason for that they don't want to face cost of cash. The variations in the cash plans or organizations permit writers to determine the reasons which type of companies to grip suitable amount of cash to its latent implication. The resolutions of deployment of inner funds of business are extremely fundamental to the encounter among bosses and stockholders which gives increase to subjects of business authority (Jensen, 1986). The corporate governance tool assists managers to report the topics and cash sensitivity in the establishments.

\section{Methodology:}

Data:

The data for the different variables for the study will be obtained from balance sheet analysis published State Bank of Pakistan. Data for different corporate governance variables will be obtained from annual report of sample firms. We are taken from those firms we studies who have relevant data for all corporate governance variables. After careful convenient we obtained only 24 firms out of 150 firms that meet about criteria. The estimation period from 2006 to 2010 the period is rohbust because during this period Pakistani economy has experienced almost every face of economic cycle.

\section{Regression Model:}

For the study we will assumption Almedia et al. (2004) model with corporate governance variables. The base line regression model as his fellow:

$(\text { cashhold })_{\mathrm{i}, \mathrm{t}}=\alpha+\beta_{1}(C F)_{\mathrm{i}, \mathrm{t}}+\beta_{2}(m b r)_{\mathrm{i}, \mathrm{t}}+\beta_{3}(\text { size })_{\mathrm{i}, \mathrm{t}}+\beta_{4}(\text { volt })_{\mathrm{i}, \mathrm{t}}+\beta_{5}(\text { div })_{\mathrm{i}, \mathrm{t}}+\beta_{6}(\text { ex })_{\mathrm{i}, \mathrm{t}}+\beta_{7}(\text { nonex })_{\mathrm{i}, \mathrm{t}}+\beta_{8}(\text { cedual })_{\mathrm{i}, \mathrm{t}}+E_{\mathrm{i}, \mathrm{t}}$ Where,

$\mathrm{CF}=$ cashflow, $\mathrm{mbr}=$ market value, volt $=$ variability, div $=$ dividend, $\mathrm{ex}=$ executives directors, nonex $=$ non executive directors cedual $=\mathrm{CEO}$ duality, $\mathrm{e}=$ error term

\section{Variable Procedure:}

Where, "cash flow" is the sum of earnings before interest tax and depreciation divided by total assets minus cash. The "mbr" is the ratio of book value of total assets minus the book value of total equity plus the market value of equity to book value of assets. The "size" the size of the firms as taken control variable, size is the natural $\log$ of total assets. The "variability" is the measure the standard deviation take of cashflow to the average taken of total assets. The "dividend" the total amount of dividend divided by total assets. The executive directors and the non-executive directors are measured by the total non-executive directors divided by total 
directors whether executive or non-executive. However, the cashholding play vital role and it is measured by cash equivalents divided total assets minus cash.

PANEL DATA REGRESSION MODEL:

We will estimate common effect model. Fixed effect regression model in this case to the impact of independent variables on dependent variable.

\section{Common Effect Model:}

We estimate the following common effect model:

$(\text { cashhold })_{i, t}=\alpha+\beta_{1}(C F)_{i, t}+\beta_{2}(m b r)_{i, t}+\beta_{3}(\text { size })_{i, t}+\beta_{4}(\text { volt })_{i, t}+\beta_{5}(\text { div })_{i, t}+\beta_{6}(\mathbf{e x})_{i, t}+\beta_{7}(\text { nonex })_{i, t}+\beta_{8}(\text { cedual })_{i, t}+E_{i, t}$ Though due to the serious difficulty of basic homogeneousness, we force not be able to create generalizable effects using common effect model.

\section{Fixed Effect Model:}

Fixed effect is commanding panel data estimation practice it ales for heterogeneity by integrating a unique interest of every cross-sectional units. Supplementary it controls the preferences that may come in our estimation due to improved variables. The next fixed effect model resolve be valued in are study.

$(\text { Cash })_{\mathrm{i}, \mathrm{t}}=\alpha_{\mathrm{i}, \mathrm{t}}+\beta_{1}(\text { cashflow })_{\mathrm{i}, \mathrm{t}}+\beta_{2}(\text { mbr })_{\mathrm{i}, \mathrm{t}}+\beta_{3}(\text { size })_{\mathrm{i}, \mathrm{t}}+\beta_{4}(\text { volt })_{\mathrm{i}, \mathrm{t}}+\beta_{5}(\text { div })_{\mathrm{i}, \mathrm{t}}+\beta_{6}(\text { ex })_{\mathrm{i}, \mathrm{t}}+\beta_{7}(\text { nonex })_{\mathrm{i}, \mathrm{t}}+\beta_{8}(\text { cedual })_{\mathrm{i}, \mathrm{t}}+$ $\boldsymbol{E}_{\mathrm{i}, \mathrm{t}}$

\section{Heteroskadascity Test:}

On occasion due to the large observation and imperfect time of period, the difficult of heteroskascity arises. In order to withhold the data wherever is heteroskadascity or not, we will comportment Bausch/Phagan test for heteroskadascity under the following hypothesis:

Ho: The data is not heteroskadascity.

H1: The data is heteroskadascity

The $\mathrm{P}$ value of 0.05 or a lesser amount of will show that data is taking the tricky is heteroskadascity. In this situation we will conduct the test rohbust standard error.

\section{Housman Tests:}

Occasionally fixed effect and common effect model may provide us encounter result so in mandate to select the best model that can offer us with rohbust and generalizable consequences, we will mien Housman test in the behind hypothesis:

H1: Fixed effect result is accepted.

Ho: Common effect result is accepted.

Table-1

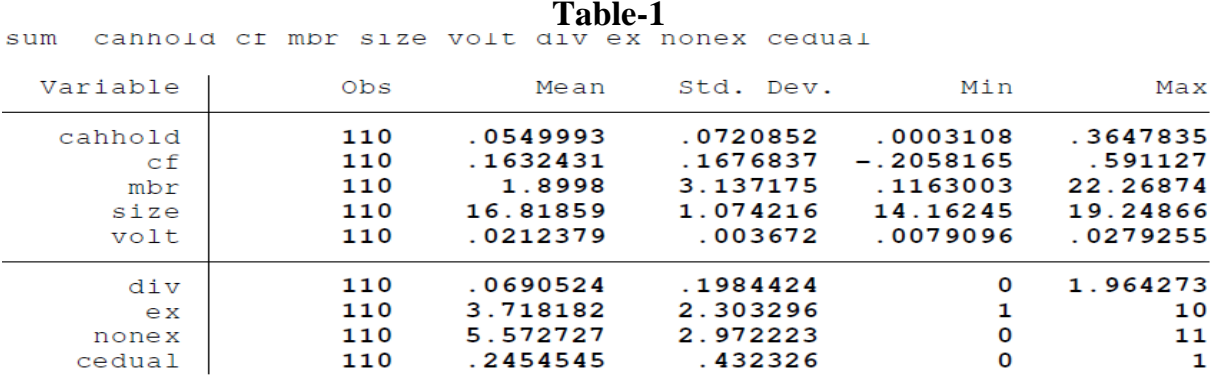

Table-2

\begin{tabular}{|c|c|c|c|c|c|c|c|}
\hline & Cahhold & $c f$ & $\mathrm{mbr}$ & size & volt & div & ex \\
\hline cahhold & 1.0000 & & & & & & \\
\hline$c f$ & 0.2780 & 1.0000 & & & & & \\
\hline $\mathrm{mbr}$ & 0.1141 & 0.4341 & 1.0000 & & & & \\
\hline size & -0.1420 & -0.1998 & -0.1252 & 1.0000 & & & \\
\hline volt & 0.1249 & 0.0002 & 0.1191 & 0.1861 & 1.0000 & & \\
\hline div & 0.0523 & 0.3975 & 0.1410 & -0.1301 & -0.0153 & 1.0000 & \\
\hline & -0.0834 & -0.1580 & -0.0479 & -0.1902 & -0.0726 & -0.1427 & 1.0000 \\
\hline nonex & -0.0089 & 0.1367 & 0.0263 & 0.4628 & 0.4740 & 0.1776 & -0.6221 \\
\hline \multirow[t]{2}{*}{ cedual } & 0.0983 & 0.0729 & 0.1331 & 0.2065 & 0.1251 & -0.0253 & -0.1602 \\
\hline & nonex & cedual & & & & & \\
\hline nonex & 1.0000 & & & & & & \\
\hline cedual & -0.0176 & 1.0000 & & & & & \\
\hline
\end{tabular}


.The table-1 shows the result of Descriptive Statistics, where mean, standard deviation shows in the table-1.

\section{Correlation:}

The table-2 indicates that there is no significant correlation among independent variables that indicates the absence of multi-correlated among of variables.

\section{Common Effect Model:}

\begin{tabular}{|c|c|c|c|c|c|}
\hline & \multicolumn{5}{|c|}{ Appendix-1 } \\
\hline Source & SS & df & MS & Number of obs & 110 \\
\hline Model & .077544289 & 8 & .009693036 & Prob $>F$ & 0.0535 \\
\hline Residual & .488849819 & 101 & .004840097 & R-squared & 0.1369 \\
\hline Total & .566394107 & 109 & .005196276 & Root MSE & .0695 \\
\hline
\end{tabular}

\begin{tabular}{r|rrrrrr}
\hline Cahhold & Coef. & Std. Err. & $t$ & P $|t|$ & [95\% Conf. Interval] \\
\hline cf & .1330014 & .0494055 & 2.69 & 0.008 & .0349943 & .2310086 \\
mbr & -.0013147 & .0024074 & -0.55 & 0.586 & -.0060903 & .0034609 \\
size & -.0049496 & .0080515 & -0.61 & 0.540 & -.0209215 & .0110223 \\
volt & 4.616917 & 2.336107 & 1.98 & 0.051 & -.0172907 & 9.251124 \\
div & -.0191271 & .037606 & -0.51 & 0.612 & -.0937273 & .0554731 \\
ex & -.005561 & .0042221 & -1.32 & 0.191 & -.0139366 & .0028145 \\
nonex & -.0055209 & .0042931 & -1.29 & 0.201 & -.0140373 & .0029954 \\
cedual & .0059026 & .0175063 & 0.34 & 0.737 & -.0288253 & .0406304 \\
cons & .0722923 & .1366122 & 0.53 & 0.598 & -.1987096 & .3432941
\end{tabular}

\section{Regression Result:}

We started our estimation by coding common effect model with standard error in (Appendix-1). The result indicates the significant and positive coefficient for cashflow. However we cannot realize those result until we have conducting heteroskadascity test, the result of heteroskadascity as follows:

Ho: Constant variance if the researcher gets the "P" value is 0.05 or less.

\section{Appendix-2 Hettest Test}

Breusch-Pagan / Cook-Weisberg test for heteroskedasticity

Ho: Constant variance

Variables: fitted values of cahhold

$$
\operatorname{chi} 2(\mathbf{1})=\mathbf{2 3 . 0 5}
$$

Prob $>$ chi $2=\quad \mathbf{0 . 0 0 0 0}$

\section{Result And Discussion:}

The outline or methodology that "P" value of Breusch-Pagan/Cook heteroskadascity test is less than 0.05 that indicates that our data is heteroskadastic. In the appendix-2 Hettest indicates that "P" is less than 0.05 tell us that data is heteroskadastic. Thus we are conducting the entire model with Rohbust Standard Error. The table-3 and table-4 represent the result of Common Effect Model and Fixed Effect model with Rohbust standard error. The table- 3 shows the result common effect model, the common effect model indicates the positive significant coefficient of cashflow and volt. However, all the corporate governance variables are insignificant and negative. In the result of research, we have seen that indicators of the market show that Pakistani producing organization's grip further cash out of their working cashflow. So therefore convictions deeply on cash their outflow. In addition to that findings, indicator of the variability are optimistic and important that businesses facing uncertainty tend to grip more financing out of their cashflow. Keynes model shows the concepts of defensive cause of cash, the outcome evidently indicate that businesses facing unreliable periods tend to grasp more cash with their own. In table No 04, it is demonstrated the outcome of immovable outcome model that do not entirely settle with the outcome of mutual outcome model. The result of that model specifies that cashflow and marketplace to book percentage is optimistic and important factor, while cedual has negative important factor with cashholding. The results of immovable outcome model is also associated with Almedia et al. (2004), that shows the same response of taking further cash out of their operational cashflow. The outcome seriously trusts on cash that specifies Pakistani businesses investment optimistic NPV their plan from their inner cashholding. On the other hand, an additional very vital outcome is worthy of the market to book percentage. The outcome specifies that businesses with advanced development chance to grasp more cash out of their 
working cashflow. The result encoding the study of Fazzari et al. (1988) found evidence that firms facing higher growth opportunities tend to hold more cash out of cash flow. In table-3 another result shows that CEO duality is positive and insignificant dividend policy of the Pakistani manufacturing firms listed on the KSE-100 index. This positive relationship indicates that in the firms where CEO and chairman hold the same post, thus chance of the decision to pay dividend increases. Thus one person chairman as well as CEO of the board who has strongly monitors the board and avoid the misuse of cash balances to declare the dividend payment. Another important result in table-4 indicates that CEO duality negatively and significantly related to the performance of the manufacturing firms. This means that firms when CEO and chairman of the board are hold by same person. In this situation the firms hold more cash out of their cashflow according to Lam and Lee (2012). We will base on conclusions on the findings by fixed effect model because it has superior periodic power.

Table-3

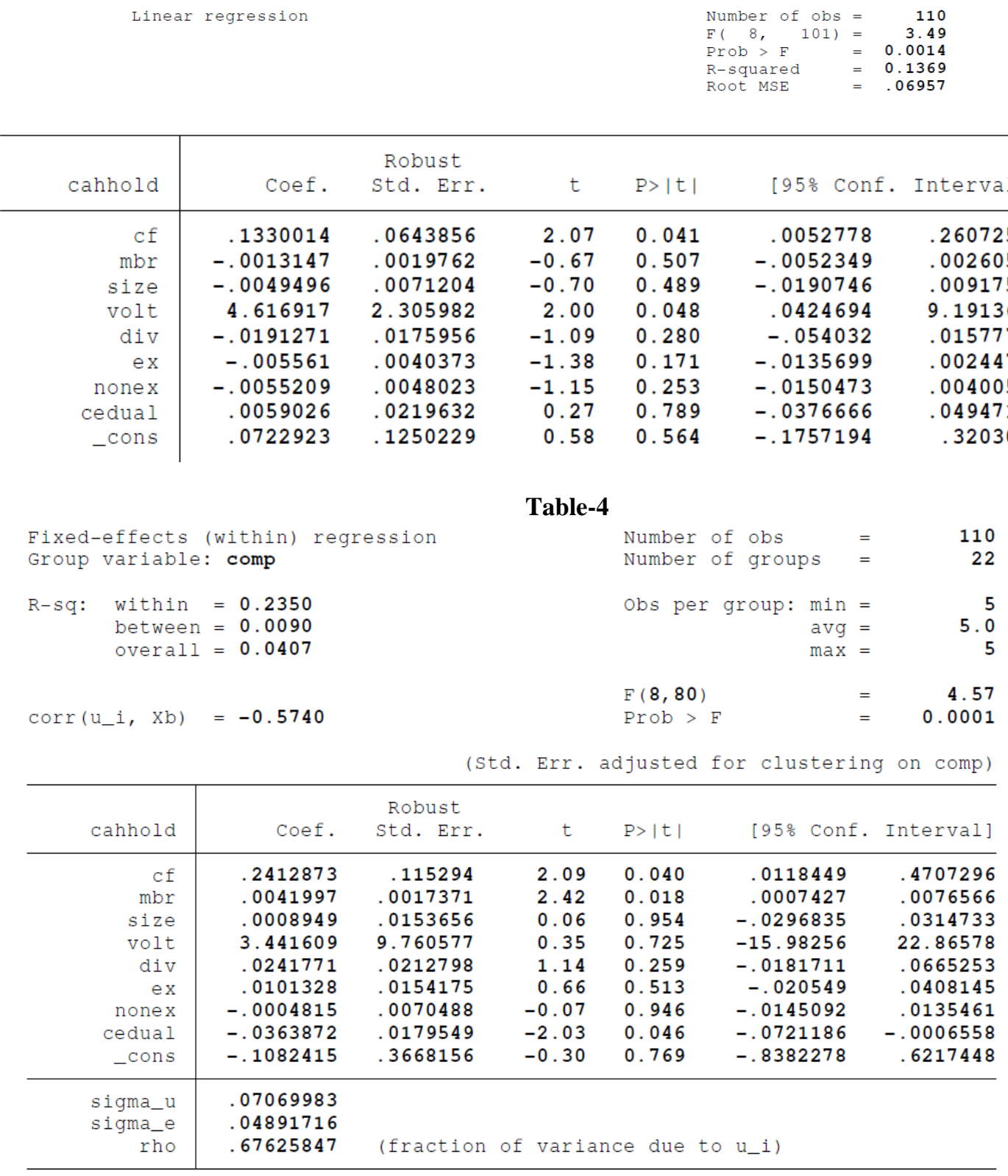

\section{Conclusion:}

In this research paper it has been found that cashflow and volt or variability are positive significant variables others that dividend, executive directors, non-executive directors and CEO duality are negative variables. In this research paper all the others variables that market to book ratio, size, dividend, executive directors, and non-executive directors and CEO duality are insignificant variables. The result indicates that variability and non-executive directors have an inverse relation with cashholding and the non-executive director's presence of firms for more cash holdings. According to the literature review the result indicates that 
corporate governance adherence to reduce the information symmetry and thus firms get more external finance easily. In this case firms to hold less cash and establish trust among the stakeholders. The result shows that if more variability to hold less cash because if more variability. It will cause to rise debt servicing and affected the cashholding will be negatively. In this case the danger will rise because people will hold more cash due to precautionary motive. Another result indicates that if cashflow will rise it with have a direct relation with cashholding which will rise because the amount of capital will rise which causes to cashholding to rise also. The variability case is same to cashflow because the variability also will be directly related to the cashholding. The overall result shows that Pakistani manufacturing firms are hold more cash because there two mainly reasons they hold this cash for mainly two reasons that are precautionary and investment motives.

\section{References:}

[1]. Attig, N., Cleary, S.W., El Ghoul, S., Guedhami, O. (2012b). Institutional investment horizon and investment-cash flow sensitivity. Journal of Banking \&Finance $(36,1164-1180)$

[2]. Dittmar, A., Mahrt-Smith, J., \& Servaes, H. (2003). International corporate governance and corporate cash holdings. Journal of Financial and Quantitative Analysis, $(38,111-133)$.

[3]. Wei, K.C.J., Zhang, Y. (2008). Ownership structure, cash flow, and capital investment: Evidence from East Asian economies before the financial crisis. Journal of Corporate Finance (14, 118-132).

[4]. Keynes, J.M., (1936). The General Theory of Employment. In: Interest and Money. Harcourt Brace, London.

[5]. Bates, T., Kahle K., and R. Stulz (2009), Why to U.S. firms hold so much more cash than they used to?, Journal of Finance (64, 1985-2021).

[6]. Foley, C., Hartzell, J., Titman, S. and G. J. Twite (2007). "Why Do Firms Hold So Much Cash? A Tax-Based Explanation”. Journal of Financial Economics (86, 579-607).

[7]. Kaplan, S., \&Zingales, L. (1997). Do financing constraints explain why investment is correlated with cash flow? Quarterly Journal of Economics, (112, 169-2).

[8]. Fazzari, S., Hubbard, R.G., \&Petersen, B.C. (1988). Financing constraints and corporate investment. Brookings Papers on Economic Activity, (141-195).

[9]. Harford, J., Mansi, S.A., \& Maxwell, W.F. (2005).Corporate governance and firm cash holdings. Working paper, University of Washington, Virginia Tech and University of Arizona.

[10]. Acharya, V., Almeida, H., \& Campello, M. (2006).Is cash negative debt? A hedging perspective on corporate financial policies. London Business School working paper, London, England.

[11]. Nguyen, P. (2005).How sensitive are Japanese firms to earnings risk? Evidence from cash holdings. School of Banking \& Finance, University of New South Wales, NSW (2052), Sydney, Australia.

[12]. Modigliani, F., \& Miller, M.H. (1958). The cost of capital, corporation finance and the theory of investment. American Economic Review, (48, 261-97).

[13]. Jensen, M., 1986. Agency costs of the free cash flow, corporate finance and takeovers. American Economic Review (76, 323-329).

[14]. Wei, K.C.J., Zhang, Y. (2008). Ownership structure, cash flow, and capital investment: Evidence from East Asian economies before the financial crisis. Journal of Corporate Finance $(14,118)$ 